\title{
FOOD SELF-SUFFICIENCY UNDER THE GREEN-MOROCCO PLAN
}

\author{
Abdelmajid Saidi ${ }^{1}$, Mohammed Diouri ${ }^{2} *$ \\ ${ }^{1}$ Department of Economics, Moulay Ismail University, Meknes, Morocco / Pacte-Grenoble, France \\ ${ }^{2}$ Biology department, Moulay Ismail University, Meknes, Morocco
}

Received - April 20, 2017; Revision - June 07, 2017; Accepted - June 12, 2017

Available Online - August 31, 2017

DOI: http://dx.doi.org/10.18006/2017.5(Spl-1-SAFSAW).S33.S40

KEYWORDS
Green-Morocco Plan
food
self-sufficiency
security
cereal

\begin{abstract}
This paper seeks to know whether the Green-Morocco Plan (GMP), the new Moroccan agricultural strategy launched in 2008, improves food self-sufficiency. In view of the importance of cereals in Moroccans' diet, the volatility of foods price in the international market, the population increase and the competition that is not always fair, long-term availability and physical access of people to food should be ensured. Self-sufficiency, which is one of the indicators of food safety, must therefore become a priority again. GMP is so far showing some positive results. Morocco reduced the poverty rate. The Agricultural Gross Domestic Product improved as well as agricultural employment and agricultural export of some products. However, one of the policies adopted by GMP is the conversion of cereal farming to arboriculture. Under this policy, cereal imports increased, without being covered by an adequate food export increase. The Green-Morocco Plan makes Morocco increasingly dependent on the world market either to export its agricultural products or to import its needs for cereals. From an environmental point of view, fruits require more water than do cereals for their production. Therefore, we believe that grain crops must be encouraged to ensure food security. As for fruit trees cultivation, it should be encouraged on lands that are not suitable for cereals, such as mountains and rugged terrains.
\end{abstract}

* Corresponding author

E-mail: m.diouri@fs.umi.ac.ma (Mohammed Diouri)

Peer review under responsibility of Journal of Experimental Biology and Agricultural Sciences.

Production and Hosting by Horizon Publisher India [HPI] (http://www.horizonpublisherindia.in/).

All rights reserved.
All the article published by Journal of Experimental Biology and Agricultural Sciences is licensed under a Creative Commons Attribution-NonCommercial 4.0 International License Based on a work at www.jebas.org.

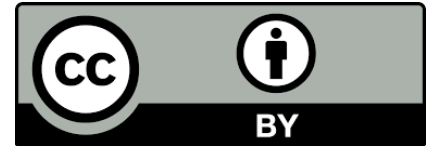




\section{Introduction}

The Green Morocco Plan (GMP) is a national strategy, launched in 2008, whose main objectives, by 2020, are the improvement of the Moroccan agriculture productivity on the basis of modern technologies and the consolidation of its position on both domestic and international markets (MAMF, 2008). As the deadline approaches, GMP is showing very positive results, according to the government.

As a means of fighting food insecurity, Morocco reduced the poverty rate, measured at US \$ 1 per day per person, from $3.5 \%$ in 1985 to almost zero in 2014, while the target was $1.8 \%$ by 2015 in the Millennium Development Goals (HCP 2015a). In both urban and rural areas, this form of poverty is virtually eradicated. At a threshold of US \$ 2 per day per person, poverty affected only $1.3 \%$ of Moroccans ( $0.3 \%$ of urban and $2.9 \%$ of rural people) in 2014. As for hunger eradication, the proportion of the population not reaching the minimum level of calorific intake, as measured by the food poverty rate, was reduced from $4.6 \%$ in 1985 to $0.1 \%$ in 2014 , with a target value of $2.3 \%$ by 2015 . In 2014 , only $0.6 \%$ of the rural population was in food poverty. In cities, hunger is virtually eradicated (HCP, 2015b). As a result, Morocco has been able to combat food poverty, and thus improve economic and physical access to food. However, Morocco is called upon to redouble its efforts to eradicate children multidimensional poverty. Morocco had 1.2 million poor children in 2014. Multidimensional poverty is mostly found among children aged 5 to 6 , with a rate of $21 \%$, compared with $7.3 \%$ for children aged 7 to 14 years. This is mainly a rural phenomenon (HCP, 2017).

Moreover, Morocco enjoys a high level of political stability, which makes it possible to improve its population's economic and physical access to food. The Agricultural Gross Domestic Product improved significantly, registering an average annual growth rate of $7.6 \%$ between 2008 and 2014. As for agricultural employment, it registered a $23 \%$ increase. In the same period, agricultural exports of some products were increased by $40 \%$ (MAMF, 2014; EACCE, 2016).

However, when it comes to the pattern of imports, the share of food products increased from $9.8 \%$ to $10.1 \%$ over the period 2008-2014. The growth rate of food exports was 5.2\% between 2008 and 2014, showing a decrease of 1.1 percentage points compared with the 2000-2007 period (MEF, 2015). In value terms, agricultural imports and exports increased, between 2008 and 2014, from MAD $^{1} 40.4$ billion to 44.5 billion and from MAD 15.2 billion to 18.6 billion, respectively (MAMF, 2015). This situation shows some limits of GMP, and leads us to question its ability to ensure food self-sufficiency.

We will then wonder about the interdependencies between policies adopted by GMP and food availability, which is

1. MAD (The Moroccan Dirham) is the Moroccan currency. determined, among other things, by food production. We have limited ourselves to a policy that, in our opinion, directly affects sustainable availability of foodstuffs and, therefore; food security of Moroccans. This is the policy of conversion of cereal farming to arboriculture.

Before discussing the relationship between GMP and food selfsufficiency, particularly with regard to cereals, we will briefly review the importance of self-sufficiency as a tool to combat food insecurity.

\section{Self-sufficiency and food security}

The food security of a country can be measured in four dimensions (Table 1): physical availability of food, economic and physical access to food, biological use of food, and economic and political stability (FAO, 2008; FAO, 1996). We do not intend here to address all these dimensions to see whether GMP improves food safety. But we will choose some key indicators related to the issue of availability and stability, namely: food production and the dependency ratio on cereal imports.

Table 1 Four main dimensions of food security (FAO, 2008)

\begin{tabular}{|c|l|}
\hline $\begin{array}{c}\text { Physical } \\
\text { AVAILABILITY } \\
\text { of food }\end{array}$ & $\begin{array}{l}\text { Food availability address the "supply side" of } \\
\text { food security and is determined by the level of } \\
\text { food production, stock levels and net trade }\end{array}$ \\
\hline $\begin{array}{c}\text { Economic } \\
\text { and physical } \\
\text { ACCESS to } \\
\text { food }\end{array}$ & $\begin{array}{l}\text { An adequate supply of food at the national or } \\
\text { international level does not in itself guarantee } \\
\text { household level food security. Concerns about } \\
\text { insufficient food access have resulted in greater } \\
\text { policy focus on incomes, expenditure, markets } \\
\text { and prices in achieving food security objectives. }\end{array}$ \\
\hline $\begin{array}{c}\text { Food } \\
\text { UTILIZATION }\end{array}$ & $\begin{array}{l}\text { Utilization is commonly understood as the way } \\
\text { the body makes the most of various nutrients in } \\
\text { the food. Sufficient energy and nutrient intake } \\
\text { by individuals is the result of good care and } \\
\text { feeding practices, food preparation, diversity of } \\
\text { the diet and intra-household distribution of } \\
\text { food. Combined with good biological utilization } \\
\text { of food consumed, this determines the } \\
\text { nutritional status of individuals. }\end{array}$ \\
\hline $\begin{array}{c}\text { dimensions } \\
\text { over time } \\
\text { the other }\end{array}$ & $\begin{array}{l}\text { Even if your food intake is adequate today, you } \\
\text { are still considered to be food insecure if you } \\
\text { have inadequate access to food on a periodic } \\
\text { basis, risking a deterioration of your nutritional } \\
\text { status. Adverse weather condition, political } \\
\text { instability, or economic factors (unemployment, } \\
\text { rising food prices) may have an impact on your } \\
\text { food security status. }\end{array}$ \\
\hline
\end{tabular}

These are factors that measure self-sufficiency, especially in the case of Morocco, where $60 \%$ of food energy supplies come from cereals; despite increasing urbanization and changing feeding trends (Belloute \& Diouri, 2015; FranceAgriMer, 2015). On average, the consumption of the main cereals in $\mathrm{kg} /$ year / 
inhabitant is around $200 \mathrm{~kg}$, given that the world average cereal consumption is $152 \mathrm{~kg}$ / year / inhabitant. Soft wheat accounts for almost $70 \%$ of urban cereal consumption and $66 \%$ of the rural one. This consumption increases with the increase in population (33.8 million inhabitants in 2014 vs. 20 million in 1981) and in urbanization in Morocco (HCP, 2015b). Nearly 60\% of Moroccans lived in urban areas in 2014. This leads to increasing food requirements for a population with a Mediterranean diet based on cereals.

According to FAO (2009a), global demand for food, feed and fiber will increase by $70 \%$ by 2050 , while more and more crops will be used for the production of bioenergy and for other industrial purposes. Urbanization will continue to grow at an accelerated rate, and about 70 per cent of the world's population will be urban. The levels of income will be multiplied. Most of this increase will take place in developing countries. To meet this growing demand, food production must increase by $70 \%$. Annual production of cereals will have to reach about 3 billion tons compared to 2.1 billion tons in 2009.

Many countries will continue to depend on international trade for their food security. By 2050, net cereal imports by developing countries are estimated to have more than doubled, by 2050, from 135 million metric tons in 2008/09 to 300 million (FAO, 2009a). However, the world trade system does not guarantee fair prices, based on the law of supply and demand; because of the specificity of the food market and the distortions of competition induced by some developed countries subsidizing their agriculture. The food market is characterized by price volatility and speculation with staple foods (cereals, oilseeds, dairy products, meat and sugar). It was held responsible for the 2007-2008 food crisis, the largest since 1974 (Galtier, 2009; Golay, 2010).

Rising food prices in the international market, particularly wheat, rice, soybeans and maize, have resulted in an unprecedented increase in the number of undernourished people and the increase in urban riots in a number of countries, particularly in North Africa, the Middle East and South-East Asia. These populations are severely affected by rising prices of basic commodities, because of the large share (over 50\%) of these in their budgets (UNCTAD, 2009). According to UNEP (2016), many of these same countries show high exposure to price increase, in its stress test, including Morocco, Bangladesh, Tunisia and Indonesia.

The issue of food production and self-sufficiency arises therefore; to ensure the long-term availability and physical access of people to food. This question of self-sufficiency has prompted some states (European and Gulf countries, China, etc.), via their sovereign wealth funds, to seize the most productive agricultural lands in Africa and Latin America in order to supply their own internal markets. In addition, the European Union and the United States continue to massively subsidize their farmers despite a large agro-food surplus (Bazin et al., 2005; OECD, 2016).
Self-sufficiency must therefore become a priority again for developing countries that have the possibility of producing foods. It must be central to their agricultural and food-poverty-combating policies. Taking into account these requirements, we want to know to what extent the policies adopted by GMP improve Morocco's self-sufficiency, particularly with regard to cereals.

\section{Self-sufficiency and the Green-Morocco Plan}

Under GMP, a program of conversion of cereal farming to fruit trees cultivation on 1 million ha was launched (ADA, 2012). This is the conversion of cereals, crops that are less productive and more water-greedy, according to the ministry of agriculture, towards fruit trees, especially olive trees and grapevines, and truck gardening. The objective is to reduce the area dedicated to cereals while gaining in terms of productivity (Table 2). A priori, the objective is being accomplished; since between 2000-2007 and 2008-2015, the average cereal production rose from 58.4 to 80 million quintals. This is an increase of $37 \%$ in the same cultivated area.

Table 2 Green-Morocco Plan objectives by 2020 (MAMF, 2011)

\begin{tabular}{|c|c|c|c|c|c|c|c|}
\hline & Cereals & Citrus & $\begin{array}{l}\text { Olive oil } \\
\text { industry }\end{array}$ & $\begin{array}{l}\text { Fruits and } \\
\text { vegetables }\end{array}$ & Milk & $\begin{array}{c}\text { Red } \\
\text { meats }\end{array}$ & $\begin{array}{l}\text { White } \\
\text { meats }\end{array}$ \\
\hline $\begin{array}{l}\text { Investments } \\
\text { (MAD } \\
\text { billion) }\end{array}$ & 11 & 8.9 & 16.7 & 24.2 & 11.4 & 7.8 & 5.8 \\
\hline $\begin{array}{c}\text { Target } \\
\text { increase in } \\
\text { production } \\
(\%)\end{array}$ & +45 & +146 & +280 & +142 & +131 & +75 & +116 \\
\hline $\begin{array}{l}\text { Target } \\
\text { increase in } \\
\text { cultivated } \\
\text { area }(\%)\end{array}$ & -22 & +52 & +76 & +40 & & & \\
\hline
\end{tabular}

For the 2014-2015 crop year, the three main cereals (durum wheat, soft wheat and barley) reached a record production of 115 million quintals. With a production of 56 million quintals of soft wheat, this crop shows a record production of this cereal which is a fundamental component of household consumption. This harvest level exceeded the 51 million quintals recorded during the 20122013 season. Three regions, namely Doukkala, Chaouia and El Haouz, have concentrated more than $45 \%$ of the production.

According to the Ministry of agriculture, this record production was the result of actions taken during the 2014-15 crop year in terms of intensive supervision of farmers, adequate supply of inputs (support for the marketing of selected seeds), Mechanization (approximately 7 tractors per 1000 ha in 2014/15 compared to 5 in 2007/08), irrigation water mobilization throughout the crop cycle, combined with favorable climatic conditions. In fact, it was these climatic conditions that were the key factor in this record production of cereals in 2014/15. The $2015 / 16$ season showed this very well because, due to the rainfall deficit $(42.7 \%$ of an average season), cereal production was 
estimated at 33.5 million quintals; a decrease of $71 \%$ compared to 2014/15. In terms of cereal imports, there has been an increase, since between 2000-2007 and 2008-2015, the average import volume increased from 34 million to 43 million quintals (MAPMDREF, 2017). This import increase was not covered by an adequate food export increase, as shown above.

In addition, Ait El Mekki \& Nouréini Sayouti (2015) showed that a deficit, of 3.8 million tons for soft wheat and 1.02 million tons for durum wheat, is foreseen by 2020 . These authors considered that the decline in cereal areas would not be appropriate for achieving an acceptable threshold of food self-sufficiency that would protect the country from dependence on the world market. This market is characterized by high volatility in food prices (Figure 1).

So, we question the relevance of the conversion of cereals to arboriculture, particularly in most productive regions such as
Doukkala-Abda, which yielded the highest cereal production in 2014/2015. In this region, under the Pillar 2 projects, an area of 120,000 ha of cereals is to be converted, by 2020, to fruit trees, in particular olive tree, caper, fig tree and cactus (ADA, 2017a). The question is why performing the conversion in a lowland region which contributes $14.5 \%$ (i.e. 16.7 million quintals in 2014/15) to national cereal production? Should arboriculture not be promoted in mountains and rugged terrains? This would allow these crops to benefit from the high day-night temperature differences and the quality of light radiation (Roose, 2010). Indeed, the fruit tree is an integral part of the Moroccan mountains landscape, where it is often grown on terraces.

From an environmental view point, it takes 2.09 liters of water to produce a kcal from fruits, whereas the production of a cereal kcal requires only 0.51 liters (Table 3). GMP also plans to increase beef and chicken production, by $132 \%$ and $89 \%$ respectively, in

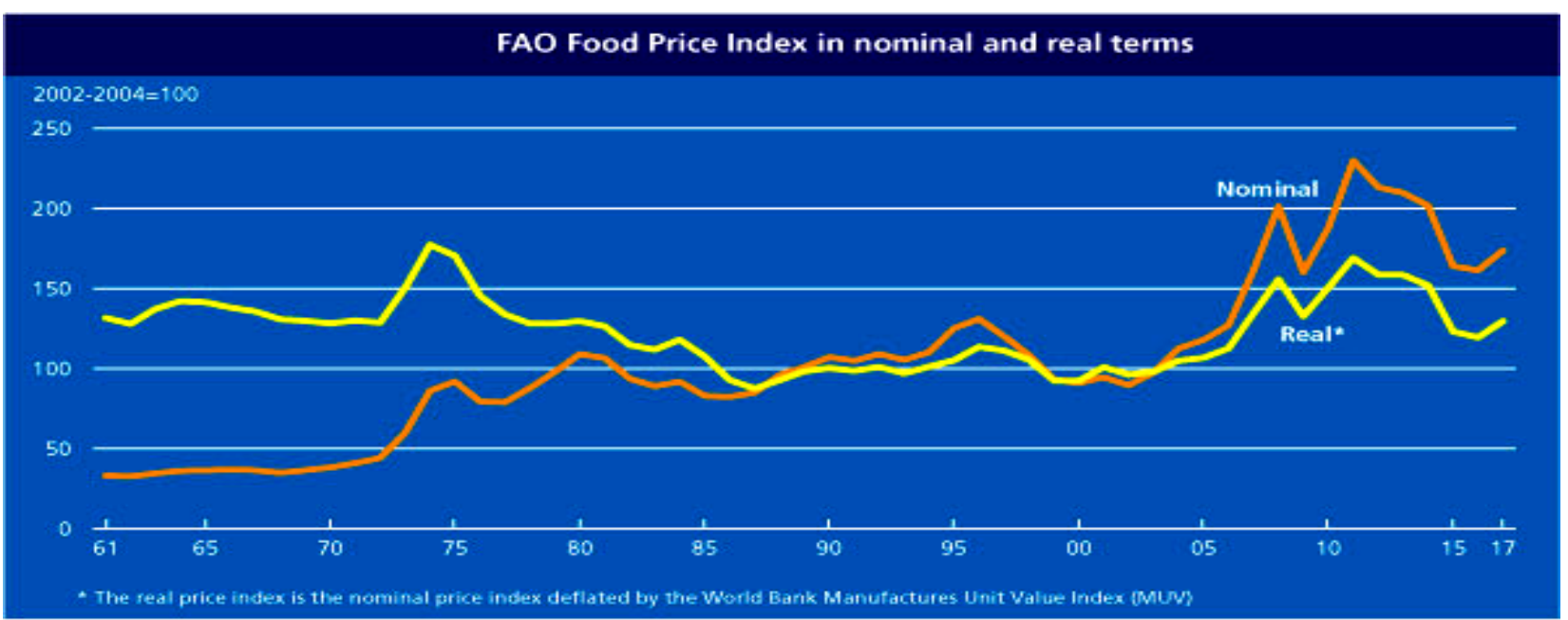

Figure1 Evolution of the FAO Food Price Index from 1961 to 2017 (FAO, 2017)

Table 3 The Water Footprint of Some Selected Food Products from Vegetable and Animal Origin (Hoekstra \& Mekonnen, 2012)

\begin{tabular}{|c|c|c|c|c|c|c|c|c|c|c|}
\hline \multirow{2}{*}{ Food Item } & \multicolumn{4}{|c|}{ Water footprint per ton $\left(\mathrm{m}^{3} / \mathrm{ton}\right.$} & \multicolumn{3}{|c|}{ Nutritional Content } & \multicolumn{3}{|c|}{ Water footprint per unit of nutritional value } \\
\hline & Green & Blue & Grey & Total & $\begin{array}{l}\text { Calorie } \\
(\mathrm{kcal} / \mathrm{kg})\end{array}$ & $\begin{array}{c}\text { Protein } \\
(\mathrm{g} / \mathrm{kg})\end{array}$ & $\begin{array}{l}\text { Fat } \\
((\mathrm{g} / \mathrm{kg})\end{array}$ & $\begin{array}{c}\text { Calorie } \\
\text { (liter/kcal) }\end{array}$ & $\begin{array}{c}\text { Protein (liter/g } \\
\text { protein) }\end{array}$ & $\begin{array}{l}\text { Fat (liter/g } \\
\text { fat) }\end{array}$ \\
\hline Sugar crops & 130 & 52 & 15 & 197 & 285 & 0.0 & 0.0 & 0.69 & 0.0 & 0.0 \\
\hline Vegetables & 194 & 43 & 85 & 322 & 240 & 12 & 2.1 & 1.34 & 26 & 154 \\
\hline Starchy roots & 327 & 16 & 43 & 387 & 827 & 13 & 1.4 & 0.47 & 31 & 226 \\
\hline Fruits & 726 & 147 & 89 & 962 & 460 & 5.3 & 2.8 & 2.09 & 180 & 348 \\
\hline Cereals & 1,232 & 228 & 184 & 1,644 & 3,208 & 80 & 15 & 0.51 & 21 & 112 \\
\hline Oil crops & 2,023 & 220 & 121 & 2,364 & 2,908 & 146 & 209 & 0.81 & 16 & 11 \\
\hline Pulses & 3,180 & 141 & 734 & 4,055 & 3,412 & 215 & 23 & 1.19 & 19 & 180 \\
\hline Nuts & 7,016 & 1367 & 680 & 9,063 & 2,500 & 65 & 193 & 3.63 & 139 & 47 \\
\hline Milk & 863 & 86 & 72 & 1,020 & 560 & 33 & 31 & 1.82 & 31 & 33 \\
\hline Eggs & 2,592 & 244 & 429 & 3,265 & 1,425 & 111 & 100 & 2.29 & 29 & 33 \\
\hline Chicken meat & 3,545 & 313 & 467 & 4,325 & 1,440 & 127 & 100 & 3.00 & 34 & 43 \\
\hline Butter & 4,695 & 465 & 393 & 5,553 & 7,692 & 0.0 & 872 & 0.72 & 0.0 & 6.4 \\
\hline Pig meat & 4,907 & 459 & 622 & 5,988 & 2,786 & 105 & 259 & 2.15 & 57 & 23 \\
\hline Sheep/ goat meat & 8,253 & 457 & 53 & 8,763 & 2,059 & 139 & 163 & 4.25 & 63 & 54 \\
\hline Beef & 14,414 & 550 & 451 & 15,415 & 1,513 & 138 & 101 & 10.19 & 112 & 153 \\
\hline
\end{tabular}

Journal of Experimental Biology and Agriculture Science http://www.jebas.org 
the Doukkala-Abda zone by 2020 . While the production of one kilogram of wheat requires 590 liters of water (CNRS, 2000), that of beef requires 15415 liters (i.e. 26 times more) and that of chicken meat requires 4325 liters (Hoekstra \& Mekonnen, 2012). In terms of calories from beef and chicken, 10.19 liters / kcal and 3 liters / kcal are required respectively.

This disagrees with the argument, put forward by GMP (ADA, 2012; ADA, 2017b), that cereals are water-intensive crops, in order to justify their conversion. But either way, the intensive use of water is preventable. In fact, the amount of water needed to produce cereals has halved since 1960 . This was possible, without depleting resources, through, inter alia, increased use of recycled wastewater in agriculture and buried drip irrigation (FAO, 2002; UNEP, 2016).

In addition, GMP aims to increase agricultural exports through the promotion of the citrus, olive-growing, fruit and vegetable sectors (MAMF, 2011). However, Morocco does not export only agricultural products, but also the locally scarce factors, in this case water contained in these products. This is done for the sake of "currency gain", which is often disappointing (Akesbi, 2011; Akesbi, 2013). These productions often involve intensive or even super-intensive practices, making heavy use of inputs that are harmful to the ecosystem. Moreover, the presence of a large quantity of insecticides in agricultural products can prevent their exports. Several agricultural products are banned in various importing countries such as olives destined for the United States or mint exported to the European Union; because of noncompliance and excessive pesticide content.

This policy, based on the promotion of agricultural exports, was accelerated in developing countries in the early 1980s, as a result of the Structural Adjustment Program (SAP), imposed on them by the IMF so that they could repay their debts. This program has forced developing countries to abandon support for their food crops, to tax basic foodstuffs rather than support them, and to open up their markets to imports, particularly agricultural ones (Firdawcy 1993; Stiglitz 2002). Growth based on agriculture, particularly on the smallholder sector, is at least twice as effective for the poor as compared to the growth of non-agricultural sectors. This is because $75 \%$ of the poor in developing countries live in rural areas; and their income is directly or indirectly related to agriculture (FAO, 2009a).

With SAP, the country practices a cash crop that is wholly export oriented; and at the same time imports its basic consumer products, putting food crops in serious difficulty. This eventually results in countries heavily dependent on imports and even food aid (Figure 2). This was the case in Egypt, which was forced to export water-intensive strawberries, at the expense of cereals. The result was that, in 1994, the country had to import 6 million tons of wheat but could only export 7 tons of strawberries (Bouguerra, 2003).

\section{Million USs}

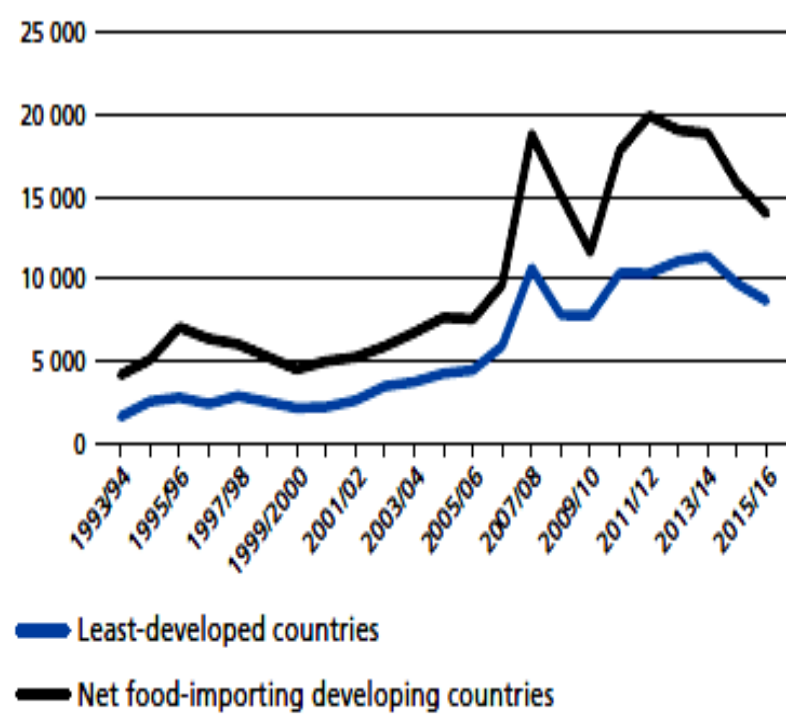

Figure 2 Cereal imports of least-developed countries and net foodimporting developing countries, 1993/94 to 2015/16 (FAO, 2015)

In addition to SAP, multilateral, bilateral and regional trade agreements have weakened the ability of developing countries to meet their food needs. As a result of the gradual removal of their customs barriers, these countries have been dumped with heavily subsidized products that have adversely affected local food production. As a result, developing countries have shifted from being net exporters of food to being net importers. Their surplus of $\$ 1.9$ billion in the 1970 s became a deficit of more than $\$ 9$ billion in 2004. Imports of cereals of low-income countries reached \$ 38 billion in 2007 (FAO, 2009b).

According to a recent report by FAO (2015) on the situation of agricultural commodity markets, the dependence of cereal importers in Africa, Asia and the Pacific on the international cereal markets will increase further (Table 4). Despite its fertile land that is being purchased at a large scale by multinationals or states, Africa will import, in 2023, almost 45 million tons of 
Table 4 Trade balance in volume terms in 2023 (FAO, 2015)

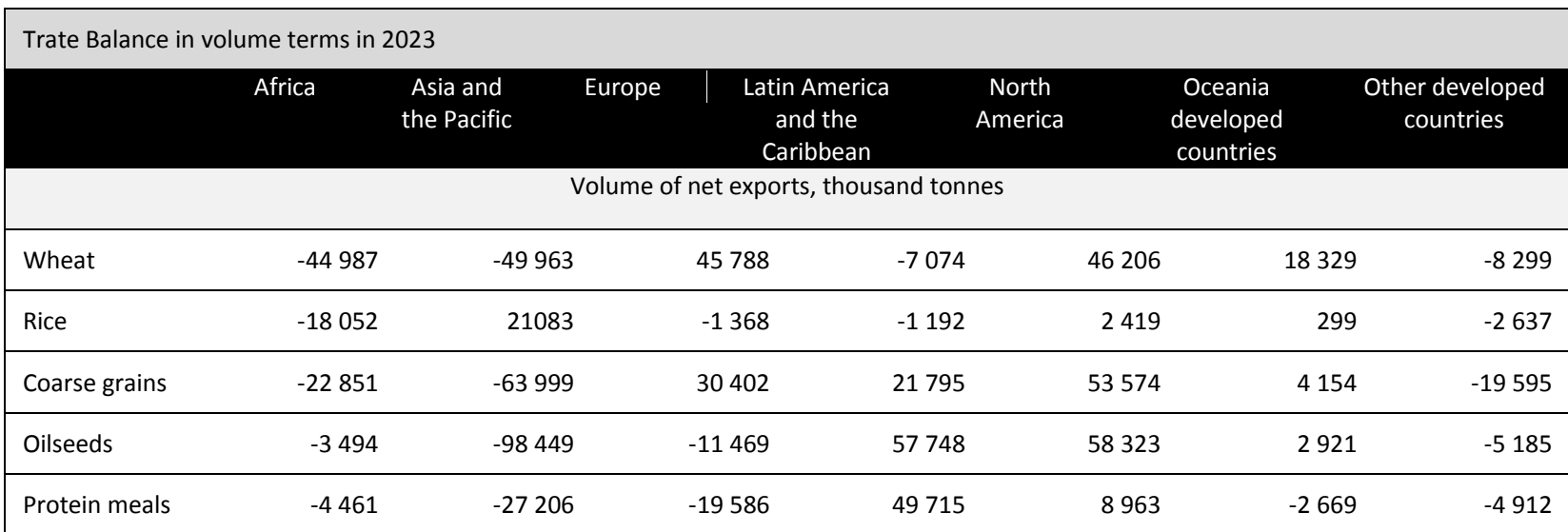

wheat and nearly 23 million tons of secondary cereals (barley, oat and sorghum).

In Morocco, as in many other developing countries, the 1990s witnessed the development of policies based on export products and the dismantling of marketing boards and most agricultural policy instruments (Achoum et al., 1992; Firdawcy, 1993). As a result, the rate of import coverage by agri-food exports has been steadily falling over the years, from $200 \%$ in the 1970 s to less than 50\% today (Oulhaj, 2013). In 2014, this coverage rate was about $42 \%$ (MAMF, 2015).

\section{Conclusion}

The Green-Morocco plan makes Morocco increasingly dependent on the world market either to export its agricultural products (tomatoes and citrus in particular), or to import its needs for cereals. Under this policy, cereal imports increased, without being covered by an adequate food export increase. In order to cope with this deterioration, we believe that grain crops must be encouraged to ensure food security, given their high share in the diet of a growing population.

In order to rationalize water consumption and combat degradation of natural resources, ecological and biological practices should be adopted. As for fruit growing, GMP should encourage it on lands that are not suitable for cereals, such as mountains, hills and rugged terrains.

In general, Morocco should encourage practices that locally and sustainably ensure the availability of basic foodstuffs for its population. Its food policy should also aim at increasing fish consumption, from $12 \mathrm{~kg}$ per capita per year to a global average exceeding $20 \mathrm{~kg}$.

\section{References}

Achoum M, Belhadfa H, Guedira A, Rami A (1992) Ajustement structurel et mise en valeur en irrigué. Communication à la Table
Ronde organisée par l'IAVHII, Wye College et l'ANAFID sur les politiques d'ajustement structurel et leurs impacts sur l'agriculture irriguée au Maroc. Agadir (Morocco), 22-23 October 1992.

ADA (2012) Evaluation environnementale stratégique du Plan Maroc Vert. Rapport Définitif - Mission 2. Available on http://www.ada.gov.ma/etude/download/Etude\%20Environnemen tale\%20et\%20sociale\%20PMV.pdf, accessed on 15 February 2016.

ADA (2017a) Plan Agricole par région - Région Doukkala Abda. Available on http://www.ada.gov.ma/ambitions?region=12, accessed on 1 June 2017.

ADA (2017b) Plan Agricole par région - Région MeknèsTafilalet. Available on http://www.ada.gov.ma/ambitions?region=8, accessed on 1 June 2017.

Ait El Mekki A, Nouréini Sayouti S (2015) Le Plan Maroc Vert et l'autosuffisance alimentaire en produits de base à l'horizon 2020. Alternatives Rurales 3: 78-90

Akesbi N (2011) La nouvelle stratégie agricole du Maroc annonce-t-elle l'insécurité alimentaire du pays ? Confluences Méditerranée 78: 93-105

Akesbi N (2013) L'agriculture marocaine, entre les contraintes de la dépendance alimentaire et les exigences de la régulation sociale. Critique économique $30: 3-27$

Bazin G , Charvet JP, Devienne S (2005) Politique agricole et agriculture aux Etats-Unis :évolution et enjeux actuels, Politique agricole et agriculture aux États-Unis : évolution et enjeux actuels. Annales de géographie 641: 3-26

Belloute R, Diouri M (2015) Consumption Habits in Morocco and Their Influencing Factors. International Journal of Scientific Research 4: 52-56

Bouguerra ML (2003) Les batailles de l'eau: pour un bien commun de l'humanité. Editions de l'Atelier, Paris, France 
CNRS (2000) Consommations agricoles. Available on http://www.cnrs.fr/cw/dossiers/doseau/decouv/usages/consoAgri. html, accessed on 20 February 2017.

EACCE (2016) Note sur les exportations des produits agricoles du Maroc vers 1'UE. Available on http://www.eacce.org.ma/wpcontent/uploads/2016/06/Note_Exportations_Agricoles_Maroc_U E.pdf, accessed on 19 March 2017.

FAO (1996) Rome Declaration on World Food Security. Available http://www.fao.org/docrep/003/W3613E/W3613E00.HTM, accessed on 15 April 2008

FAO (2002) Crops and Drops: making the best use of water for agriculture. Natural Resources Management and Environment Department. Available on ftp://ftp.fao.org/docrep/fao/005/y3918e/y3918e00.pdf, accessed on 26 March 2017.

FAO (2008) An introduction to the basic concepts of food security. Rome, EC-FAo Food Security Programme. Available on http://www.fao.org/docrep/013/a1936e/al936e00.pdf, accessed on 25 April 2017.

FAO (2009a) How to Feed the World in 2050. Available on http://www.fao.org/fileadmin/templates/wsfs/docs/expert_paper/H ow_to_Feed_the_World_in_2050.pdf, accessed on 26 June 2011.

FAO (2009b) The State of Food Insecurity in the World Economic crises - impacts and lessons learned. Available on ftp://ftp.fao.org/docrep/fao/012/i0876e/i0876e.pdf, accessed on 10 March 2010.

FAO (2015) The State of Agricultural Commodity Markets Trade and food security: achieving a better balance between national priorities and the collective good. Available on http://www.fao.org/3/a-i5090e.pdf, accessed on 18 March 2017.

FAO (2017) Food Price Index. Available on http://www.fao.org/worldfoodsituation/foodpricesindex/en, accessed on 30 April 2017.

Firdawcy ML (1993) Le développement rural au Maroc au-delà du P.A.S. Annales Marocaines d'Economie, Numéro spécial : 448-457.

FranceAgriMer (2015) Les céréales vers le Maroc. Available on http://www.franceagrimer.fr/content/download/42240/394761/file /MEP-memoire-logistique-MAROC_20160126.pdf, accessed on 01 April 2017.

HCP (2015a) Morocco between MDGs and SDGs, achievements and challenges. Available on http://www.hcp.ma/downloads/ Objectifs-du-millenaire-pour-le-developpement-Objectifs-deDeveloppement-Durable_t11877.html, accessed on 1 June 2017. HCP (2015b) L'enquête nationale sur la consommation et les dépenses des ménages au Maroc. Available on http://www.hcp.ma/Introduction-de-Monsieur-Ahmed-LAHLIMIALAMI-Haut-Commissaire-au-Plan-a-la-presentation-desresultats-de-L-enquete_a1819.html, accessed on 15 December 2016.

HCP (2017) Note d'information du Haut Commissariat au Plan A l'occasion de la Journée Nationale de l'Enfant. Available on http://www.hcp.ma/Note-d-information-du-Haut-Commissariatau-Plan-a-1-occasion-de-la-Journee-Nationale-de-1-Enfant2017_a1921.html, accessed on 26 May2017.

Hoekstra AY, Mekonnen MM (2012) Water Footprint Farm Animal Products. Ecosystems 15: 401-415.

Galtier F (2009) Comment gérer l'instabilité des prix alimentaires dans les pays en développement? Working Paper Moisa 4: 1-27

Golay C (2010) The Food Crisis and Food Security: Towards a New World Food Order? International Development Policy 1: 215-232

MAMF (2008) Strategy of Green Morocco Plan. Available on http://www.agriculture.gov.ma/en/pages/strategy, accessed on 19 April 2017.

MAMF (2011) Le Plan Maroc Vert : rapport d'étape 2008-2011. Available on http://www.marocagriculture.com/bibliotheque/planmaroc-vert/PMV-2008-2011.pdf, accessed on 18 March 2017.

MAMF (2014) L'agriculture en chiffres 2014. Available on http://www.agriculture.gov.ma/pages/publications/lagriculture-enchiffres-2014, accessed on 19 March 2017.

MAMF (2015) L'année agricole 2014/2015. Available on http://www.agriculture.gov.ma/pages/rapports-statistiques/lanneeagricole-20142015, accessed on 25 March 2017.

MAPMDREF (2017) Statistiques et Veille Economique. Available on http://www.agriculture.gov.ma/rapports-statistiques), accessed on 1 June 2017.

MEF (2015) Tableau de bord des indicateurs macro-économiques. Available on https://www.finances.gov.ma/Docs/2015/DEPF/Tableau_bord_ma cro-economique_05_2015.pdf, accessed on 1 June 2017.

OECD (2016) Agricultural Policy Monitoring and Evaluation. Available on http://www.oecd.org/tad/agriculturalpolicies/agriculture-policy-monitoring-flyer-2016.pdf, accessed on 15 May 2017.

Oulhaj L (2013) Evaluation of the Agricultural strategy of Morocco (Green Morocco Plan) with a Dynamic General Equilibrium Model. Femise research programme. Available on http://www.femise.org/etudes-et-recherches/evaluation-de-lastrategie-agricole-du-maroc-plan-maroc-vert-a-laide-dun-modeledequilibre-general-dynamique/ accessed on 15 March 2017. 
Roose E (2010) Zones de culture: amélioration des techniques culturales traditionnelles. In Laouina A, Sabir M, Roose E (Ed) Gestion durable des eaux et des sols au Maroc, IRD Éditions; Institut De Recherche Pour Le Développement, Marseille, France : 235-260

Stiglitz J (2002) La grande désillusion. Fayard, Paris (France).

UNCTAD (2009) Food security in Africa: learning lessons from the food crisis. Trade and Development Board. Available on http://repository.un.org/bitstream/handle/11176/278873/TD_B_E $\mathrm{X}(47) \_3$-EN.pdf?sequence $=3 \&$ isAllowed $=\mathrm{y}$, accessed on 15 June 2011.

UNEP (2016) Erisc Phase II: How Food Prices Link Environmental Constraints to Sovereign Credit Risk. Available on http://www.footprintnetwork.org/content/documents/ERISC_2_20 16.pdf, accessed on 19 June 2017. 